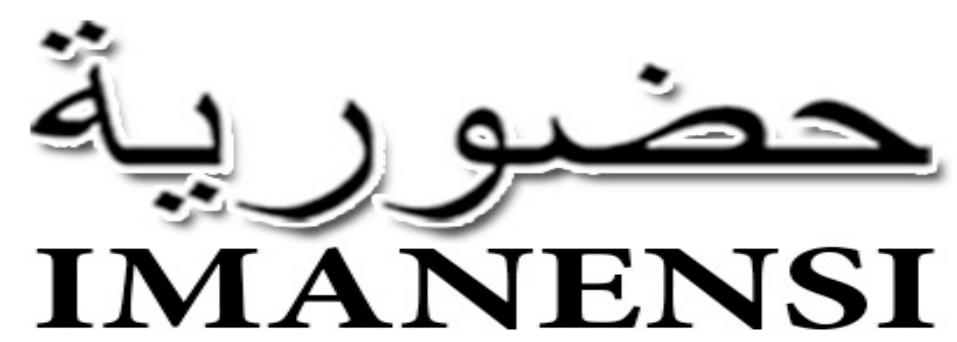

(Jurnal Ekonomi, Manajemen, dan Akuntansi Islam)

Vol 3, No 2, September 2018, Hlmn. 1-11

\title{
Intuisi: dalam proses perwujudan akuntansi berkeTuhanan
}

\author{
Siti Rodliyah, Aji Dedi Mulawarman \\ a Universitas Brawijaya, J1. Mayjen Haryono 169 Malang, Indonesia \\ 65145 \\ 1sitirodliyah626@gmail.com
}

doi: $10.34202 /$ imanensi.3.2.2018.1-11

\begin{abstract}
Abstrak
Tujuan penelitian ini adalah untuk menemukan bagaimana berpikir tentang penyerahan kepada Allah SWT dapat membawa akuntansi Islam ke akuntansi aktual yang berorientasi pada Tuhan. Metode yang digunakan adalah tinjauan pustaka, data sekunder untuk digunakan sebagai interpretasi perumusan masalah penelitian. Hasil penelitian adalah teori dan konsep akuntansi syariah, tidak dapat dipraktikkan oleh manusia yang jauh dari nilai-nilai Illahi sehingga manusia memerlukan latihan spiritual dalam menciptakan individu yang secara fisik dan mental terlibat dengan Tuhan.
\end{abstract}

Kata Kunci: Teori Akuntansi Syariah; Intuisi; Spiritual.

\section{Abstract}

The purpose of this study is to find out how intuition is able to shape human thinking into submission to Allah SWT by those who can bring Islamic accounting into actual accounting oriented to God. The method used is qualitative by using literature review. Using secondary data to be used as an interpretation of the research problem formulation. Results of the research are the purity of the theory and concept of sharia accounting, it cannot be practiced if the human being far from divine values. Therefor we need spiritual exercise in creating individuals who both physically and mentally involve God.

Keywords: Sharia Accounting Theory; Intuition; Spiritual.

This is an open access article under the CC-BY-SA license.
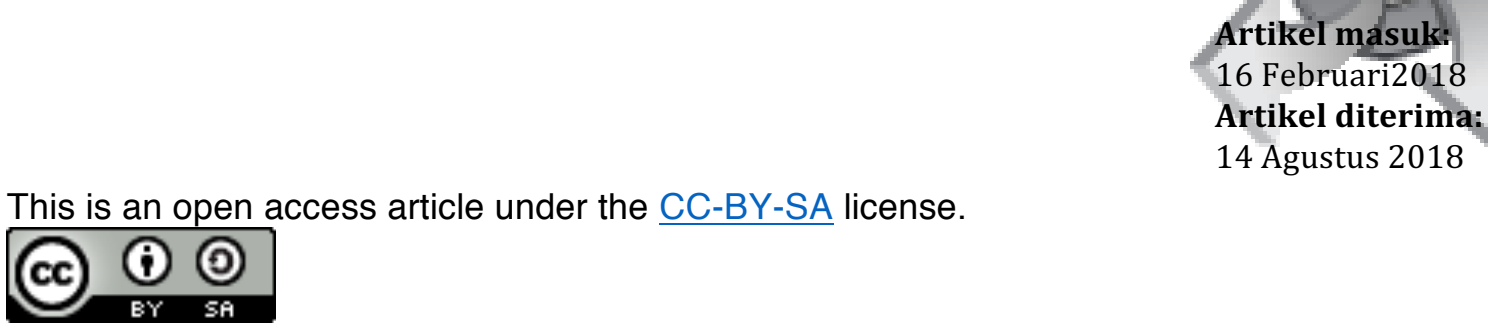
Penerapan praktik akuntansi di Indonesia sangat erat dan dekat dengan akuntansi yang berdasarkan pada paham kapitalistik. Hal ini dapat ditelusuri dari sisi konsep maupun praksis nya. Teori akuntansi yang dikembangkan dalam dunia praktisi dan pendidikan adalah teori besar yang dicetuskan oleh Jensen Mackling (1976), yaitu teori agensi. Teori ini menjelaskan bahwa adanya keterpisahan hubungan antara principal dengan agen, semua yang dilakukan oleh agen atas dasar kepentingan pemilik (Michael Jensen, 1976). Dengan penggunaan dasar ini lah akhirnya perjalanan akuntansi semakin dekat dengan paham-paham yang dibawanya. Konsep laba yang menjadi tujuan dalam bisnis, maka bisnis adalah menekan biaya serendah-rendahnya untuk memaksimal keuntungan. Jika berlandaskan pada teori keagenan maka pemaksimalan keuntungan ini menjadi tujuan utama agen dalam memenuhi tuntutan dari principal. Bahwa bisnis yang dijalankan harus dalam ranah untung dan laba. Maka jika sudah seperti ini tentu cara apapun akan mungkin dilakukan dalam memaksimalkan keuntungan. Wajah akuntansi yang telah dibentuk oleh kapitalisme dengan nyata menyebarkan informasi bagi para penggunanya untuk mengambil keputusan dan aktivitas ekonomi (Triyuwono, 2006)

Berdasarkan pada pengembangan ilmu diatas, maka timbul problematika atau kecemasan-kecemasan yang pada akhirnya dirasakan oleh umat Islam. Kita tahu bahwa di Indonesia sebagian besar penduduknya adalah Islam. Maka jika praktik keilmuan khusunya akuntansi berjalan seperti diatas maka tentu hal ini sangat bertolak belakang dengan faham syariah umat Islam. Oleh karena itulah diperlukan beberapa pemikiran dan gagasan penyeimbang, agar manusia tidaka terus menerus berada pada jalan ekonomi utilitarian dan hedonisme. Pemikiran kritis yang belandaskan prinsip ketauhidan, serta pengembangan ekonomi islam dan akuntansi syariah merupakan suatu batu loncatan untuk melakukan perubahan dan pembebasan dari ekonomi kapitalistik yang menyebabkan manusia menjadi homo economicus.

Beberapa pemikiran kritis yang telah diungkap oleh beberapa ahli ekonomi Islam dapat dijadikan landasan dalam perjalanan perubahan ekonomi Islam kedepannya. Menurut (Triyuwono, 2006), fitrah manusia dimuka bumi ini adalah bukan sebagai makhluk homo economicus, melainkan sebagai Khalifatullah fil Ardl yakni manusia sebagai hamba yang mendapat amanah dari Tuhan untuk memakmurkan bumi. Perspektif inilah pada akhirnya menjadi landasan lahirnya Syariah Enterprise Theory. Teori ini terbentuk karena kepedulian terhadap stakeholder dan lingkungan alam sekitarnya. Akuntansi yang sarat dengan bebas nilai dengan konsep laba yang dibangun. Maka teori ini, sebaliknya menggunakan konsep nilai tambah (value added) atau lebih tepatnya menggunakan shariah value added (SVA) yang kemudian nantinya disajikan dalam shariah value added statement (SVAS).

Berlandaskan pada teori dan perspektif SET, kemudian Mulawarman (2016), dalam penelitian konstruksinya memberikan alternatif 3 model statement baru, salah satunya yaitu Expanded Value Added Statement (EVAS) sebagai pengganti laporan laba rugi. Serta penambahan perspektif peran manusia bukan hanya sebagi Khalifatul Fil Ardl tetapi juga sebagai Abdullah. Selain itu, Forum Dosen Ekonomi dan Bisnis Islam (FORDEBI) juga mengangkat konsep kesejahteraan semesta. Konsep ini menegaskan pemahaman bahwa segala sesuatu milik Allah SWT, maka manusia akan memperoleh, memanfaatkan, dan mendistribusikan kekayaan sesuai dengan kehendak pemilik (FORDEBI, 2018)

Perkembangan akuntansi syariah di Indonesia kini semakin pesat yang mana dalam pekembangannya akuntansi syariah mengikuti pola kebijakan yang dibentuk oleh organisasi seperti, lembaga akuntansi syariah International yaitu Accounting and Auditing Organization for Islamic Financial Institusion (AAOIFI) lembaga inilah yang berfungsi melakukan penyeragaman perlakuan akuntansi dari lembaga keuangan syariah global dan merupakan organisasi nonprofit. Serta PSAK 101-108 yang dikeluarkan oleh IAI. Perkembangan akuntansi syariah yang demikian menimbulkan penerapan akuntansi syariah keluar dari pemaknaan yang seharusnya, hal ini justru 
membuat penerapan akuntansi cenderung pada konsep akuntansi yang berorientasi profit juga (Iswanaji, 2017)

Jika demikian yang terjadi dalam praktik, nyatanya perkembangan akuntansi syariah yang semakin pesat ini juga mengalami benturan permasalahan. Salah satu kendala terbesarnya adalah pada terbatasnya Sumber Daya Manusia (SDM) yang benar-benar memahami pemaknaan akuntansi syariah. Perlu disadari bahwa majunya lembaga keuangan syariah tidak hanya dari perkembangan teori saja, tetapi juga harus di barengi dengan para praktisi yang memahami dasar dari akuntansi syariah itu sendiri.

Jika demikian maka harus ada perbaikan dulu dari sisi SDM untuk mewujudkan akuntansi syariah sebagai ilmu yang berkeTuhanan. Menurut Iqbal (1924), dalam FORDEBI, (2018) ia menjelaskan bahwa pikiran mampu menjangkau Sang Maha Takterbatas yang imanen, karena pikiran tidaklah statis, ia dinamis yang menyingkap ketidakterbatasan internalnya waktu, tetapi organis dengan intuisi. Dari beberapa pemaparan diatas maka peneliti ingin mengetahui bagaimana intuisi mampu membentuk pemikiran manusia menjadi tunduk kepada Allah SWT dengan tujuan mampu membawa akuntansi syariah menjadi sebenarnya akuntansi yang berorientasi pada pengabdian kepada Tuhan.

\section{METODE}

Artikel ini bertujuan untuk membentuk pola fikir sumber daya manusia dalam menjadikan akuntansi syariah berkeTuhanan melalui intuisi. Penelitian ini merupakan pengembangan model konseptual, dengan melakukan telaah pustaka dari berbagai macam sumber. Dengan memaparkan bagaimana gagasan akuntansi syariah terbentuk, dan beberapa pemikiran-pemikiran praktik intuisi yang lebih bisa mendekatkan individu kepada sang Maha Kuasa. Penelitian in merupakan penelitian kualitatif interpretif, dengan menggunakan studi literature. Yang didasarkan pada data sekunder yang diperoleh berbagai jurnal, artikel, buku, internet, dan penunjang lainnya.

\section{HASIL DAN PEMBAHASAN}

Arti Penting Teori Akuntansi Syariah. Dalam praktik akuntansi sesungguhnya tidak terlepas dari teori dari akuntansi itu sendiri. Pemahaman yang benar tentang teori akuntansi jelas akan berdampak pada praktik akuntansi yang sehat pula. Secara konseptual akuntansi syariah ini hadir sebagai solusi atas perkembangan akuntansi konvensional yang tidak sesuai dan jauh dari nilai-nilai ilahiah (Apriyanti, 2018). Solusi atas teori yang dibangun ini sangat berbeda dengan akuntansi konvensional. Kita tahu bahwa teori akuntansi syariah ini dikembangkan berdasar pada al-Qur'an yang merupakan pedoman hidup umat muslim. Dan juga dikuatkan dengan hadist, sunnah, dan ijma' ulama. Sedangkan akuntansi konvensional dibangun melalui taktik cerdik dan penalaran akal sehat. Dengan adanya solusi seperti inilah diharapkan akuntansi syariah dapat menjawab serta mewujudkan baik secara konsep maupun praktik dilapangan bisa berjalan sesuai dengan nilai-nilai syariah.

Konsep akuntansi syariah yang hadir saat ini merupakan jawaban dari masalah ekonomi saat ini. Dengan pedoman yang digunakan adalah Al-qur'an dan sunnah maka akuntansi syariah yang baru ini bisa menjadi Rahmatan lil 'Alamin. Sesuai dengan Al-qur'an itu sendiri yang merupakan rahmat bagi semesta alam. Maka, model akuntansi syariah yang baru ini bukan semata-mata untuk umat muslim saja, tetapi juga bagi semua umat didunia ini. Berdasarkan pada ekonomi Islam, maka konsekuensinya baik transaksi serta kebijakan yang digunakan baik dari sisi dan praktik harus sesuai dengan kaidah-kaidah Islami (Apriyanti, 2018)

Teori akuntansi syariah menurut Triyuwono (2006), yang mengadopsi aspek muhasabah an nafs melalui ketauhidan yang mengartikan bahwa posisi manusia adalah sebagai khalifatullah fil ardl dimana manusia sebagai pemimpin dan pengelola di bumi Allah SWT dan mengembah amanah dalam mewujudkan nilai keadilan illahi, serta membawa manusia pada kesadaran ilahi melalui 3 unsur, yaitu pertaama faith yang berarti iman, kedua knowledge yang berarti ilmu, dan ketiga action yang berarti 
amal. Ketiganya merupakan pedoman yang akan menjadi dasar praktik akuntansi syariah. Wujud dari akuntansi yang akan dimunculkan adalah akuntansi yang bernilai humanis, emansipatoris, transendental, dan teleogikal yang berarti bahwa ilmu akuntansi syariah akan menuntun manusia menjadi hamba Allah dari sisi mental dan spiritual. Serta diharapkan mampu menjadi pemimpin dalam melakukan perubahan dari teori dan juga praktik akuntansi yang erat dengan sifat emansipatoris (membebaskan) diri dari jalan akidah syariah Allah SWT. Artinya manusia harus mampu mencapai fitrahnya sebagai khalifatullah fil ardl. Perspektif Khalifatullah Fil Ardl diharapkan menjadi kacamata bagi setiap individu muslim dalam melihat dan menyikapi semua aspek kehidupannya, termasuk dalam aspek pengembangan akuntansi. perspektif ini memposisikan manusia sebagai hamba yang mendapat amanah dari Tuhan.

Konsep ini membawa suatu keilmuan harus dilandaskan dengan perilaku etis setiap individu. Ketika etika ini sudah melekat pada ilmu akuntansi, maka tentunya ilmu akuntansi yang dibawa mempunyai nilai yang sarat dengan prinsip-prinsip syariah. Berdarsarka perspektif ini beliau memunculkan teori baru dalam akuntansi syariah yaitu Syaria'h Enterprise Theory (SET), teori ini menggagas bahwa akuntansi tidak lagi menggunakan konsep laba, akan tetapi menggunakan konsep nilai tambah atau value added, lebih tepatnya adalah syari'ah value added (SVA) yang kemudian akan disajikan dalam Syari'ah Value Added Statement (SVAS). Konsep ini mencoba mengubah konsep yang telah diterapkan pada lembaga keuangan yang berlandaskan Entity Theory, dimana pada teori ini sarat dengan nilai-nilai kapitalisme yang mengutamakan aspek materi sebagai tujuan utama. SET ini menggunakan berprinsip pada falsafah sufi Manunggaling Kawulo Gusti laporan akuntansi syariah dengan menggunakan Neuro Linguistic programming dan Neuroscience dapat dirancang untuk menyajikan informasi Dzikrullah yaitu informais yang berfungsi sebagai doa. Informasi Dzikrullah tidak hanya mencakup semua informasi mental dan spiritual, tetapi juga informasi materi. Sehingga akunatnsi syariah itu sendiri memiliki tiga bentuk laporan yaitu Laporan Komitmen Tauhid (LKT), Laporan Rahmat Allah (LRA) dan Laporan Amanah Allah (LAA) yang semuanya berfungsi sebagai doa dan dzikir yang dapat mengubah sirkuit sistem syaraf otak para pengguna untuk membentuk citra Allah dan perilaku positif seperti yang terkandung dalam laporan tersebut.

Tidak ada pemisahan antara kehidupan manusia dan kenyataan. Realitas fisik bersatu dengan mental, spiritual, dan Realitas Absolut (Tuhan). Tuhan menjadi tujuan akhir. Oleh karena itu, akuntansi dalam konteks ini diperlakukan sebagai instrumen untuk membimbing manusia untuk mencapai tujuan akhir (Triyuwono, 2013). Akuntansi syariah diharapkan menjadi alternatif akuntansi. Secara normatif dikonseptualisasikan berdasarkan prinsip-prinsip Islam di mana tujuan akhir kehidupan Muslim adalah kembali kepada Tuhan, yang dalam istilah Al-Qur'an dinyatakan dalam pernyataan innaalillaahiwainnaailaihiraaji-uun. Hal ini mengartikan bahwa keilmuan juga mencerminkan nilai-nilai keTuhanan. Tuhan bukan hanya ditempat ibadah, akan tetapi juga berada disemua lini keilmuan. Jika kita menghadikan ini maka sesungguhnya kittelah berhasil dari jeruji sikap sekularisme. Ilmu dan praktik akuntansi dapat memberikan jalan untuk kita mendekatkan diri kepada sang khaliq (Muhammad dan Mulyati, 2018). Dalam bahasa arab akuntansi dapat dimaknai sebagai muhasabah, maka akuntansi merupakan sebuah alat untuk dijadikan pertanggungjawaban. Dalam HR. Bukhori yang artinya: .." dan hambaku yang selalu mendekatkan diri kepadaKu dengan perkara-perkara sunnah diluar fardhu maka aku akan mencintainya, dan jika aku telah mencintainya maka aku adalah pendengarannya yang digunakan untuk mendengar, penglihatnnya yang digunakan untuk melihat, tanganya yang digunakan untuk memukul dan kakinya yang digunakan untuk berjalan. Hadist tersebut dapat memberikan makna bahwa jika kita (sebagai hamba) senantiasa mendekatkan diri kepadanya dalam hal apapun, maka sejatinya Allah akan mencintainya (hamba tersebut). Dan apabila Allah telah mencintai, maka sungguh Allah lah tujuan dari penglihatan, pendengaran, dan arah untuk perjalanannya. 
Secara epistemologis, ilham mengarahkan kita cara menyusun informasi akuntansi syariah. Dalam konteks akuntansi syariah, jenis informasi tidak terbatas pada informasi kuantitatif-finansial, tetapi juga informasi kualitatif-nonkeuangan. Masuk akal karena akuntansi syariah mencoba menangkap realitas holistik yang menyertai suatu transaksi. Suatu transaksi yang disampaikan oleh perusahaan sebenarnya rumit. Ini melibatkan transaksi fisik dan transaksi non-fisik. Biasanya, akuntansi modern hanya mengakui transaksi fisik yang melibatkan pertukaran barang dan jasa. Pertukaran kemudian diukur, disederhanakan, dan dinyatakan dalam istilah moneter. Ini menjadi informasi akuntansi, informasi keuangan kuantitatif. Namun, akuntansi syariah tidak hanya mengenali transaksi fisik, tetapi juga mental dan spiritual. Dalam transaksi nyata, katakanlah, menukar barang dan jasa dengan sejumlah uang, ada transaksi mental dan spiritual. Ketika seorang penjual menjual barang atau jasa dengan perasaan bahagia dan dengan kesadaran (Triyuwono, 2013)

Teori akuntansi selanjutnya adalah teori dari Mulawarman, beliau merumuskan dengan struktur secara berurutan, yaitu yang pertama adalah tujuan dari akuntansi syariah itu sendiri yaitu bentuk realisasi kecintaan kepada Allah sehingga pertanggungjawaban pencatatan sampai dengan pelaporan secara mental dan spiritual harus sesuai dengan nilai-nilai syariah (Mulawarman, 2009). Hal ini berusaha menunjukkan adanya upaya takhalluq bi akhlaqillah yang dapat menjadi kebiasaan mahabbah. Berkaitan dengan mahabbah ini telah dijelaskan di dalam QS. Al-Maidah : 54 yang artinya "..barang siapa diantara kamu yang murtad dari agamanya, maka kelak Allah SWT akan mendatangkan suatu kaum. Dia mencinta mereka dan mereka pun mencintai-Nya..". Tauhid dan Mahabbah dalam teori akuntansi syariah berbasis urf. Urf yang dimaksud disini adalah "urf syaari" yaitu masuk kedalam nuskhakh batin salinan batin kehadiran ilahi dalam diri manusia. Namun, dalam aspek lahirnya adalah urf manusia untuk ber takhalluq bi akhlaqillah yaitu ketaatan mutlak dalam bentuk pengalaman hukum amaliah dalam praktik beribadah maupun bermuamalah secara benar dan terus menerus. Dalam konsep dasara kuntansi syariah ini bentuk pertanggungjawaban kepada Allah harus juga memiliki implikasi horizontal kepada seluruh makhluk dibumi. Konsep ini juga merupakan implikasi dari SET, yaitu teori yang mempunyai makna luas dari suatu entitas atau perusahaan. Dalam upaya amaliah akuntansi untuk mewujudkan distribusi kesejahteraan juga harus memenuhi kriteria-kriteria yang dibentuk yaitu halal, thayyib dan bebas riba. Kriteria inilah yang kemudian dijadikan prinsip dan karakter akuntansi syariah.

Postulat dan prinsip dasar akuntansi Islam diturunkan berdasarkan tujuan laporan keuangan dibuat yaitu untuk kemaslahatan muammalah. Hal inilah yang kemudian dijadikan landasan dalam pengukuran dan pengungkapan informasi akuntansi dalam upaya mendukung kemslahatan. Prinsip akuntansi syariah ini diunkapkan dalam pernyataan yang dapat dipertimbangkan dalam melaksanakan praktik akuntansi syariah. Hal tersebut termuat dalam standar akuntansi syariah (Hadi, 2018)

Teori akuntansi syariah juga dikembangkan oleh beberapa pemikir pragmatis, contoh saja menurut (Harahap, 2001) ilmu sangat penting dalam dalam menyusun dan menguji prinsip akuntansi yang digunakan dalam penyusuan laporan keuangan yang dibuat dengan tujuan untuk disajikan kepada para pemakainya sehingga lebih bermanfaat dan sesuai dengan nilai-nilai syariah. Tujuan akuntansi syariah adalah Amar ma'ruf nahi munkar, yaitu prinsip dasar yang dikembangkan untuk menegakkan kebaikan dan menjauhi kemunkaran. Hal ini tentu sejalan dengan prinsip keadilan dan kebenaran dalam wujud kemashlahatan sosial yang akan berdampak pada saling bersinerginya kerjasama antar semua pelaku ekonomi.

Dari beberapa pemikir teori akuntansi diatas dapat kita fahami bahwa lahirnya akuntansi syariah ini merupakan konstruksi perubahan untuk menjadikan ilmu akuntansi menjadi lebih baik dan benar. Baik dan benar ini di dasarkan pada prinsip umat muslim, yakni dengan bernafaskan nilai-nilai ilahiah. Sehingga akuntansi yang benar secara teori akan dapat dipraktikkan dengan benar pula. 
kebenaran yang bukan hanya berdasar atas perspektif manusia, tetapi lebih jauh yakni kepada sang Khaliq (Tuhan semesta alam).

Konsep Sharia Value Added Statement (SVAS). Dalam upaya melakukan konstruksi atas akuntansi konvensional, akuntansi syariah hadir dalam bentuk teknologi baru yang mencoba mengganti laporan laba rugi dengan Value Added Statement (VAS) (Mulawarman et al., 2016). Perkembangan VAS dapat dilihat dari terwujudnya akuntansi sosial dan lingkungan yang diwujudkan dalam program Corporate Social Responsibility (CSR) pemikiran ini masih erat dengan aliran, yakni sebuah pemikiran yang masih mempertahankan status quo akuntansi tradisional. Aplikasi CSR ini adalah perwujudan dari VAS sebagai bentuk laporan tambahan. Laporan ini belum sepenuhnya merepresentasikan atas sebenar-benarnya laporan keungan, hal ini dapat dilihat di tabel yang diusulkan oleh Mook et al, (2005) dalam (Mulawarman et al., 2016). Oleh karena itu dalam mengantisipasi hal ini mereka memberikan beberapa model statement baru, salah satunya adalah Expanded Value Added Statement (EVAS) sebagai pengganti laporan laba rugi.

EVAS merupakan konsep pengembangan dan perluasan dari konsep VAS. Karena didalam VAS menunjukkan peran organisasi yang berhubungan dengan esensi manfaat masyarakat secara umum masih dominan diabaikan dalam output laporan keuangan, karena hal tersebut berkaitan dengan transaksi yang tidak dapat dimoneterisasi. EVAS merupakan bentuk perluasan yang mencoba menunjukkan integrasi informasi finansial maupun non-finansial dengan sintetis data finansial input dan output sosial. Gabungan antara data finansial dan non-finansial serta input dan output sosial akan memberikan gambaran secara menyeluruh dari aktivitas ekonomi perusahaan baik berdampak langsung maupun tidak langsung. Bentuk rekonstruksi akhir yang mencoba diusulkan adalah Shariah Value Added Statement (SVAS). Hal ini berdasar konsep VA dan SVA yang telah dirumuskan.

Rekonstruksi SVA dimaknai sebagai pertambahan nilai (zakka) material (zaka) dan telah disucikan (tazkiyah) secara spiritual untuk memberikan ketenangan batin. Implikasinya, pertama, proses pembentukan VA dilakukan secara konsisten dengan cara melaksanakan aktivitas ekonomi dalam batas-batas yang diperbolehkan syariat. Yaitu halal dan thoyib. Sebaliknya aktivitas ekonomi yang melanggar syariat dihukumi haram. Kedua, pertumbuhan harta dan mekanisme usaha yang sehat harus dilakukan dalam upaya menghilangkan menghilangkan segala usaha yang berlebihan dalam pemaksimalan laba dengan cara yang melanggar syariat yaitu mengurangi pemanfaatan riba dalam apapun bentuknya. Dari sisi kepentingan sosial dan lingkungan, melakukan praktik pengurangan riba dengan melakukan relasi sosial dan lingkungan alam secara pro-aktif berlandaskan prinsip shadaqah. Ketiga, implikasi bentuk distribusi VA, proses penyucian (Tazkiyah) harus dilakukan secara optimal yang berorientasikan pada kebaikan secara menyeluruh dan merata. Menetapkan prinsip keadilan dan keseimbangan berdasarkan prinsip keTuhanan. Yang akan berwujud pada kesejahteraan sosial melalui proses Tazkiyah. Implementasi SVA yaitu dalam bentuk laporan kuantitatif dan kualitatif SVAS, yang memiliki unsur-unsur materi dan non-materi yang berbeda dengan konsep laporan keuangan yang dibentuk selain dari akuntansi syariah (Mulawarman et al., 2016)

\footnotetext{
Akuntansi Syariah: Kesejahteraan Semesta. Konsep selanjutnya yang dibangun dalam upaya mewujudkan kemurnian nilai akuntansi syariah baik dalam teori ataupun praktik. Yaitu suatu konsep kesejahteraan semesta yang dibangun oleh tim FORDEBI (Forum Dosen Ekonomi dan Bisnis Islam). Kesejahteraan semesta dibangun berdasarkan prinsip ketauhidan. Yakni mengakui keesaan Allah, semua yang ada dibumi ini milik Allah SWT. Maka fitrah manusia sebagai khalifatullah fil ardl harus memanfaatkan kekayaan ini sebaik-baiknya untuk kepentingan bersama dan berorientasi kepada Allah SWT. Selain itu menggunakan prinsip wakaf sebagai bentuk penghambaan dalm ikrar inna shallati wanusuuki wa ma yahya wa ma maati lillahi robbil alamiin. Sektor riil terintegratif syariah serta syirkah dengan nilai-nilai berbasis masjid yang juga merupakan prinsip dasar kesejahteraah semesta.ketiga prinsip inilah yang dijadikan pondasi dalah mencapai tujuan fallahdari kesejahteraan semesta (FORDEBI, 2018).
} 
Tabel 1

Bentuk Rekonstruksi Akhir yaitu Laporan Kuantitatif Shari'ate Value Added Statement

\begin{tabular}{lllll}
\hline & Penciptaan VA & Finansial & $\begin{array}{c}\text { Sosial \& } \\
\text { Lingkungan }\end{array}$ & Combined \\
\hline Output & Ketundukan Primer & $\mathrm{Xa}$ & - & $\mathrm{Xa}$ \\
& Ketundukan Primer & $\mathrm{Xb}$ & - & $\mathrm{Xb}$ \\
& Kreativitas Primer & - & $\mathrm{Ya}$ & $\mathrm{Ya}$ \\
& Kreativitas Sekunder & - & $\mathrm{Yb}$ & $\mathrm{Yb}$ \\
& Jumlah Output & $\mathrm{Xc}$ & $\mathrm{Yc}$ & $\mathrm{Za}$ \\
\hline Input & Ketundukan Sekunder & $\mathrm{Xd}$ & - & $\mathrm{Xd}$ \\
\hline Revaluation & Kreativitas Primer & $\mathrm{Xe}$ & - & $\mathrm{Xe}$ \\
& VA Kotor & $\mathrm{Xf}$ & $\mathrm{Yd}$ & $\mathrm{Zb}$ \\
\hline
\end{tabular}

TAZKIYAH $(\mathrm{Zc})$

Pembayaran Zakat kepada 8 Asnif $(Z d)$

VA HALAL DAN THOYYIB (Ze)

\begin{tabular}{lllll}
\hline & Distribusi VA & Finansial & $\begin{array}{c}\text { Sosial \& } \\
\text { Lingkungan }\end{array}$ & Combined \\
\hline Internal & Ketundukan Sekundes & $\mathrm{Xg}$ & - & $\mathrm{Xg}$ \\
Karyawan & Ketundukan Primer & $\mathrm{Xh}$ & & $\mathrm{Xh}$ \\
& Kreativitas Primer & $\mathrm{Xi}$ & - & $\mathrm{Xi}$ \\
Owners & Kreativitas Sekunder & $\mathrm{Xj}$ & - & $\mathrm{Xj}$ \\
Reinvestment Funds & & & \\
\hline Eksternal & Ketundukan Primer & $\mathrm{Ye}$ & $\mathrm{Ye}$ \\
Pemerintah & Kreativitas Sekunder & $\mathrm{Yf}$ & $\mathrm{Yf}$ \\
& Ketundukan Sekunder & - & $\mathrm{Yg}$ & $\mathrm{Yg}$ \\
Residents & Kreativitas Sekunder & - & $\mathrm{Yh}$ & $\mathrm{Yh}$ \\
Masyarakat & & & & \\
\hline
\end{tabular}

Strategi pengembangan kesejahteraan semesta merupakan integrasi nilai masjid yaitu ubudiyah, pendidikan, dan keumatan dengan strategi umum pada sektor, interdisiplin, dan budaya. Strategi ini dikembangkan dengan Satial connectography, artinya pengembangan setiap sektor akan berkelindan dengan sektor lainnya, serta terhubung dengan kewilayahan. Strategi yang akan dibangun menggunakan metodologi nubbuwah sirkuler (sejarah perjalanan kenabian). Metodologi ini membagi strategi dalam beberapa periode, yaitu: 1) strategi dakwah pembangkitan kesadaran melalui pendidikan, 2) strategi pengembangan dan penetapan kebijakan dan regulasi, 3) strategi pengayaan institusi pendukung, 4) strategi implementasi dan penguatan kebijakan dan regulasi

Dalam perumusannya pada tahap awal beberapa sektor yang akan dibahas dalam arsitektur kesejahteraan semesta antara lain, adalah: pendidikan, kesehatan, pertanian, kelautan dan perikanan, pertambangan dan energy, produksi strategis (otomotif, teknologi informasi, dll), perdagangan, keuangan

Konsep pengembangan kesejahteraan semesta adalah dimulai dari masjid. Masjid merupakan simbol dan identitas dalam spiritual umat Islam. Dari jaman dahulu masjid sebenarnya bukan hanya sebagai tempat beribadah, melainkan kegiatanOkegiatan lain yang dapat menyatukan umat bisa dilakukan disana. Dalam konsep ini mencoba menjadikan masjid sebagai tempat untuk memfasilitasi berbagai upaya pemberdayaan dan penguatan pada bidang pendidikan, budaya, dan berbagai disiplin didang lainnya.

Untuk mewujudkan berbagai konsep diatas maka, diperlukan strategi yang sesuai dengan rumusan nubbuwah sirkuler. Tahapan strategi tersebut adalah: a) Strategi dakwah Dakwah Pembangkitan Kesadaran melalui Pendidikan. Pada tahap ini berkisar sekitar 7 tahun (misal, 2017-2024); b) Strategi Pengembangan dan 
Penetapan Kebijakan dan Regulasi. Tahap ini berkisar sekitar 6 tahun (misal, 20242030); c) Strategi Pengayaan Institusi Pendukung. Tahap ini berkisar sekitar 5 tahun (misal, 2030-2035); 4) Strategi Implementasi dan Penguatan Kebijakan dan Regulasi. Tahap ini berkisar sekitar 6 tahun (misal, 2035-2040).

Beberapa tahapan strategi diatas akan berlaku pada seluruh sektor yang akan dijangkau dalam rumusan kesejahteraan semesta. Yakni dalam sektor pendidikan, kesehatan, pertanian, dan sektor lainnya. Dengan terbentuknya konstruksi baru dari kesejahteraan semesta inilah diharapkan semua pelaku ekonomi dapat merasakan pemerataan hasil. Tidak ada pihak yang merasa menguasai kekayaan alam ini. dengan demikian kesejahteraan semesta akan dapat membawa individu memaknai dirinya sendiri sebagai khalifatullah fil ardl, jika manusia telah sadar hal ini, maka manusia tidak akan sewenang-wenangnya dalam mengelolan dan memanfaatkan kekayaan alam dibumi ini. Apapun yang dilakukan tentulah mencerminkan ketauhidan kepada Allah SWT. Dapat juga menyelaraskan diri dalam upaya terjaganya agama, jiwa, keturunan, akal, harta, dan lingkungan melalui keseluruhan instrumen-instrumen kesejahteraan. Dapat meningkatkan kualitas manusia yang menyadari bahwa ia adalah hamba yang patuh dan tunduk kepada pencipta, dengan menjadikan kesejahteraan duniawi sebagai jalan meraih kebahagiaan ukhrawi (Akhirat).

Lembaga Pembentuk Kebijakan Akuntansi Syariah. Organisasi global yang bertugas dalam penyelarasan kebijakan akuntansi syariah adalah AAOIFI (Accounting and Auditing Organization for Islamic Financial Institusion). Organisasi ini berkontribusi untuk mempertahankan nexus imperialisme-akuntansi dalam proses pengembangan pemikiran dan standar akuntansi Islam " global " (Kamla \& Haque, 2017). AAOIFI didirikan oleh sejumlah IFI pada 1990-an setelah serangkaian skandal di industri perbankan Islam. Hal ini dikarenakan kekhawatiran IFI terkait dengan meningkatnya kecurigaan umat Islam tentang sifat Islami dari produk-produk akuntansi syariah. AAOIFI dihadapkan dengan tugas yang sulit menggabungkan nilai-nilai agama dengan prasyarat pasar modal dari efisiensi dan standarisasi dalam pengambilan keputusan dalam upaya pengembangan standar akuntansi.

Menurut Mulawarman \& Kamayanti (2018) akuntansi syariah di Indonesia tidak mengikuti AAOIFI. Ketua Dewan Standard Akuntansi Syariah (DSAS) menyatakan belum mengadopsi standar AAOIFI karena standar AAOIFI hanya berurusan dengan lembaga keuangan dan tidak berurusan dengan pihak yang bertransaksi dengan lembaga. Standar AAOIFI terlalu luas dan kurang terperinci karena hanya berkaitan dengan audit dan akuntansi. Akhirnya DSAS mengadopsi kerangka kerja kerangka kerja konseptual IFRS, yang disesuaikan untuk pasar, terutama pasar modal (meskipun ada pernyataan, seperti PSAK 109 dan 110, yang tidak hanya mengatur produk keuangan, mirip dengan pernyataan oleh AAOIFI). Pernyataan Standar Akuntansi Syariah (PSAK) 101-110 mengadopsi akuntansi konvensional, yang berorientasi pada akumulasi modal (tercermin dalam Pembagian Keuntungan dan Kerugian / PLS.

Pada kenyataan ini bisa diketahui bahwa kebijakan standar akuntansi syariah merupakan harmonisasi dari berbagai standard akuntansi global. Hal tersebut juga terjadi di Indonesia, PSAK 101-110 masih beracuan atau mengadopsi standar akuntansi IFRS. Artinya bahwa konsep akuntansi syariah yang telah gamblang dipaparkan. Seperti rumusan teori-teori dari beberapa ahli tidak didukung dengan regulasi yang menanunginya. Konsep dan teori yang dibangun berlandaskan pada Alqur'an, hadist, dan sunnah. Sedangkan regulasi atau kebijakan yang dibentuk berdasarkan harmonisasi standard IFRS yang notabene itu adalah pedoman akuntansi konvensional.

Intuisi Pembentuk Spiritualitas Manusia. Perilaku manusia adalah gabungan dari pembelajaran dan pengalaman. Bagaimana subjek manusia individu akan berperilaku dan bereaksi dalam keadaan tertentu dan akan sepenuhnya bergantung pada pandangan bahwa jiwanya ingin dia melihat situasi atau peristiwa tertentu (Bilal, Ayesha, \& Zareen, 2010). Oleh sebab itu manusia akan berperilaku berubah-ubah 
sesuai dengan kejadian tertentu. Oleh sebab itulah dibutuhkan individu yang mempunyai pedoman akhlak yang kuat untuk tetap mempertahankan sikap yang dibawanya. Pedoman akhlak ini dapat ditandai dengan kekuatan spiritual agamanya, semakin ia berkomitmen pada agamanya, maka ia juga akan semakin berkomitmen terhadap melakukan suatu tindakan tertentu, simal dalam pekerjaannya.

Saat ini manusia telah dihadapkan pada kemajuan zaman yang sangat fenomenal. Hal ini tentu sangat wajar karena ini merupakan wujud dari berkembangnya suatu ilmu pengetahuan dan teknologi. Kemajuan ini berorientasi pada materi yang akan membuat manusia merasa bahagia. Perkembangan yang seperti ini tentu sangat kita harapkan, karena kita menjadi manusia modern yang tidak gaptek (gagap teknologi) artinya kita bisa dapat menghadapi peliknya persaingan global. Akan tetapi kemajuan ini malah menadi pemisah manusia dengan alam, batin, dan Tuhannya. Manusia modern melek akal akan tetapi buta hati. Akibatnya telah banyak terjadi seperti bencana alam yang sering kita temui baik di Indonesia maupun diluar negeri. Bila kita menyadari itu semua merupakan akibat dari butanya hati, manusia memandang materi semata dengan mengesampingkan alam yang ditinggali dan Tuhan maha Pencipta (Triyuwono, 2006)

Perlu adanya suatu kebiasaan serta keistiqomahan manusia untuk dapat membuka diri terhadap kepedulian alam dan batin, karena dengan cara tersebut akan dapat membantu manusia mengahamba kepada Tuhannya. Sehingga dapat menumbuhkan sikap spiritual dari seorang manusia, yang selalu merasa diawasi oleh Tuhannya. Maka berdasarkan pemikiran ini seharusnya akuntansi tidak hanya beorientasi dengan materi semata, akan tetapi juga berorientasi pada alam rasa dan alam batin, yang akan mengantarkan manusia mengenal Tuhannya (Triyuwono, 2006). Maka perlu dilakukan olah batin, dengan menggunakan hati yang intuitif yang nantinya dapat dipraktikkan secara nyata. Mengasah batiniyah diri dengan harapan akan dapat inspirasi dan pemahaman dari Sang Maha Kuasa. Olah batin ini dapat dilakukan dengan berdzikir (senantiasa mengagungkan nama Tuhannya) secara terus menerus. Dengan cara inilah diyakini dapat memperkuat intuisi (kemampuan memahami sesuatu tanpa melalui penalaran rasional).

Menurut Triyuwono, (2006) intuisi merupakan energi spiritual yang juga meliputi energi psikis yang dapat dijadikan jalan untuk menuju Tuhannya. Olah batin (spiritual exercise) merupakan cara yang efektif yang dapat dilakukan untuk menghubungkan hati manusia dengan sang pencipta. Dibawah ini ditunjukkan beberapa latihan dalam upaya olah batin manusia, yaitu:

Latihan 1

1. Lakukan latihan ini pada malam hari, yaitu ketika anda akan mengakhiri semua kegiatan dan akan beristirahat untuk tidur

2. Tidur dalam keadaaan posisi tubuh yang santai dan rileks

3. Kemudian, ucapkan kalimat-kalimat thoyyib untuk Allah SWT ( contoh: subhanallah,astaghfirullah, laa ilaaha illah, alhamdulillah, d1l) dengan bersuara selama 10 menit

4. Selanjutnya, lanjutkan dzikir tersebut dalam hati sampai anda tertidur

Latihan 2

1. Lakukan latihan ini pada saat anda sedang melakukan aktivitas, atau bekerja.

2. Kemudian, ucapkan kalimat-kalimat thoyyib untuk Allah SWT ( contoh: subhanallah, astaghfirullah, laa ilaaha illah, alhamdulillah, dll)

3. Lakukan dzikir tersebut dalam jangka waktu yang lama (sesuai keinginan hati)

Latihan 3

Jika suatu saat anda menginginkan informasi dari "atas", maka lakukan latihan

3 ini dengan berharap meminta informasi kepada Yang Maha Kuasa

1. Lakukan latihan 1 dan 2 secara rutin setiap hari

2. Lakukan shalat tahajjud sebanyak rakaat yang bisa dilakukan 
3. Lakukan dzikir sesuai dorongan hati, dengan mata terpejam dan konsentrasi penuh pada dzikir tersebut

4. Lalu, konsentrasikan perhatian anda pada keluar masuknya udara melalui nafas. Hal ini dilakukan sampai benar-benar konsentrasi dan tidak ada fikiran yang mengganggu

5. Setelah tenang, merasa rileks, dan santai kemudian tanyakan sesuatu yang ingin diketaui kepada Allah SWT

6. Jika anda memperoleh jawaban berupa simbol-simbol,maka cobalah untuk memahami maknanya. Jika belum paham maka tanyakan lagi kepada Allah hingga anda benar-benar faham

7. Setelah mendapatkan pemahaman, maka beryukurlah. Kemudian buka mata dan latihan selesai.

Latihan-latihan diatas merupakan upaya olah batin manusia untuk memperkuat intuisi dari dalam diri manusia itu sendiri. Peneliti meyakini bahwa energi spiritualitas (intuisi) dapat diasah dengan cara olah batin seperti diatas. Dengan selalu mengingat Allah dimanapun manusia berada maka secara tidak langsung intuisi manusia telah menyatu dengan sang Pencipta. Jika demikian maka untuk menumbuhkan energi spiritualitas yang tentu dimiliki oleh seseorang akan berdampak pada praktik-praktik yang dilakukan termasuk disini praktik akuntansi. Apabila individu yang menjalankan praktik akuntansi merupakan individu yang selalu mengingat Allah (energi spiritualitasnya kuat), akhirnya akan berdampak pada kemurnian praktik akuntansi syariah yang bernafaskan Ilahiah.

\section{SIMPULAN}

Lahirnya akuntansi syariah merupakan suatu konstruksi baru dalam melakukan praktik-praktik ekonomi yang tidak berorientasi pada materi dan kesejahteraan entitas semata. Akuntansi syariah lahir untuk menjadi solusi, bahwa ekonomi islam mampu untuk mewujudkan tatanan kesejahteraan secara merata dan adil. Dengan berlandaskan pada pengakuan manusia sebagai khalifatullah fil ardl dan Abdullah dimuka bumi. Manusia mendapatkan amanah untuk memakmurkan bumi Allah. Maka semua yang kita lakukan haruslah berorientasi pada Allah serta kemashlahatan bersama. Dalam mewujudkan hal tersebut maka diperlukakan sosok manusia yang secara dhohir dan batin mampu menjangkau hal-hal yang bersifat nonmateriil. Artinya manusia yang mempunyai spiritualitas tinggi (intuisi). Ketika manusia memmpunyai intuisi yang kuat maka kemurnian pratik akuntansi akan mudah dijalankan. Hal ini tentu dapat menjawab beberapa isue yang marak, bahwa ternyata praktik-praktik akuntansi syariah masih jauh dari kemurnian akuntansi syariah itu sendiri. Penyabab utamanya adalah karena sumber daya nya lah yang ternyata masih jauh dari kemurnian nilai spiritualitas. Maka dari itu sumber daya insani lah yang mampu menjalankan praktik akuntansi syariah yang berkeTuhanan.

\section{DAFTAR RUJUKAN}

Apriyanti, H. W. (2018). Akuntansi Syariah: Sebuah Tinjauan Antara Teori Dan $\begin{array}{llll}\text { Praktik. Jurnal Akuntansi Indonesia, } & 6(2), & 131 .\end{array}$ https://doi.org/10.30659/jai.6.2.131-140

Bilal, K., Ayesha, F., \& Zareen, H. (2010). Human Resource Management: An Islamic Perspective. Asia-Pacific Journal of Business Administration, 2(1), 17-34. https://doi.org/http://dx.doi.org/10.1108/MRR-09-2015-0216

FORDEBI. (2018). Kesejahteraan Semesta. Jakarta: Yayasan Rumah Peneleh.

Hadi, D. A. (2018). Pengembangan Teori Akuntansi Syariah di Indonesia. Jurnal Akuntansi Multiparadigma, 9(1), 106-123. https://doi.org/10.18202/jamal.2018.04.9007

Iswanaji, M. C. (2017). Formalitas Fikih dalam Penerapan Akuntansi Syariah Aliran Pragmatis, (39), 583-599.

Iwan Triyuwono. (2006). Perspektif, Metodologi, dan Teori Akuntansi Syariah. Jakarta: PT Raja Grafindo. 
Kamla, R., \& Haque, F. (2017). Islamic accounting, neo-imperialism and identity staging: The Accounting and Auditing Organization for Islamic Financial Institutions. Critical Perspectives on Accounting, 1-20. https://doi.org/10.1016/j.cpa.2017.06.001

Kurniawan Muhammad dan Mulyati Sri. (2018). Akuntansi Spiritual antara "Innalillahi wa Innailaihi Raji'un" dan "Lakum Diinukum wa Liyadiin" Sebuah Studi Komparasi antara Pertanggungjawaban Universal dan Parsial. Akuntansi Dan Keuangan Islam, 6 (1).

Michael Jensen, W. M. (1976). Theory of the Firm: Managerial Behavior, Agency Costs and Capital Structure. Journal of Financial Economics, 305-360.

Mulawarman, A. D. (2009). Akuntansi Syariah: Teori, Konsep dan Laporan Keuangan. Jakarta: E-Publishing.

Mulawarman, A. D., \& Kamayanti, A. (2018). Towards Islamic Accounting Anthropology. Journal of Islamic Accounting and Business Research, 9(4), 629647. https://doi.org/10.1108/jiabr-02-2015-0004

Mulawarman, A. D., Triyuwono, I., \& Ludigdo, U. (2016). REKONSTRUKSI TEKNOLOGI INTEGRALISTIK AKUNTANSI SYARI'AH: SHARFATE VALUE ADDED STATEMENT. Jurnal Akuntansi Dan Keuangan Indonesia, 4(1), 1-24. https://doi.org/10.21002/jaki.2007.01

Sofyan Syafrie Harahap. (2001). Menuju Perumusan Teori Akuntansi Islam. Jakarta: Pustaka Quantum.

Triyuwono, I. (2006). Akuntansi Syari'ah: Menuju Puncak Kesadaran Ketuhanan Manunggaling Kawulo-Gusti. Pidato Pengukuhan Guru Besar Akuntansi Syariah.

Triyuwono, I. (2013). So, What is Shariah Accounting. Jurnal Ekonomi, Manajemen Dan Akuntansi Islam, 1(1), 42-49. 